Research Article

\title{
Genotoxic potential of the latex from cotton-leaf physicnut (Jatropha gossypiifolia L.)
}

Pedro Marcos de Almeida ${ }^{1,2}$, Silvany de Sousa Araújo ${ }^{1}$, Maria Aparecida Marin-Morales ${ }^{3}$, Ana Maria Benko-Iseppon ${ }^{1}$ and Ana Christina Brasileiro-Vidal ${ }^{1}$

${ }^{1}$ Laboratório de Genética e Biotecnologia Vegetal, Departamento de Genética, Universidade Federal de Pernambuco, Recife, PE, Brazil.

${ }^{2}$ Laboratório de Genética, Departamento de Saúde, Universidade Estadual do Piauí, Teresina, PI, Brazil.

${ }^{3}$ Laboratório de Mutagênese, Departamento de Biologia,

Universidade Estadual Paulista "Júlio de Mesquita Filho", Campus de Rio Claro, Rio Claro, SP, Brazil.

\begin{abstract}
Jatropha gossypiifolia L. (Euphorbiaceae), popularly known as cotton-leaf physicnut, is a milky shrub notable for its medicinal properties. The present study aimed to evaluate the toxic, cytotoxic and genotoxic effects of the latex of $J$. gossypiifolia, using Allium cepa L. as test system. Seeds of $A$. cepa were exposed to five concentrations of the latex $(1.25 ; 2.5 ; 5 ; 10$ and $20 \mathrm{~mL} / \mathrm{L})$ in order to evaluate parameters of toxicity (evaluation of root growth), cytotoxicity (mitotic index frequency) and genotoxicity (frequency of chromosome alterations). The latex showed a significant decrease in root mean growth value as well as mitotic index for the tested concentrations, except for $1.25 \mathrm{~mL} / \mathrm{L}$, when compared to results from the negative control. The 1.25, 2.5 and $5 \mathrm{~mL} / \mathrm{L}$ concentrations induced significant chromosome adherences, C-metaphases and/or chromosome bridges, as genotoxic effects. The significant frequency of chromosome bridges also indicated mutagenic potential for chromosomes of $J$. gossypiifolia as discussed in the paper. Considering that the latex is used in popular therapies, and that the test system $A$. cepa presents good correlation with tests carried out in mammals, it can be pointed out that its use for medicinal purposes may be harmful to human health especially if ingested.
\end{abstract}

Keywords: Allium cepa test, medicinal plant, plant latex, genotoxicity evaluation.

Received: May 21, 2014; Accepted: August 16, 2014.

\section{Introduction}

For thousands of years, several plants have been used in popular medicine. Despite being considered the main source of antimutagenics and antioxidants (Çelik and Aslantürk, 2010) some of their phytochemicals may cause adverse reactions or have potential of interacting with other medications, generating toxic, cytotoxic, mutagenic and genotoxic effects (Pawlowski et al., 2012; Ping et al., 2012; Ray et al., 2013). However, for many of them there is little information available regarding the potential health risks at short, mid- or long term (Nunes et al., 2012).

Jatropha gossypiifolia L. (Euphorbiaceae), commonly known as bellyache bush, black physicnut or cotton-leaf physicnut, is a shrub that contains a characteristic latex largely used for medicinal purposes, though in an empirical way (Cordeiro and Secco, 2014). The leaves are

Send correspondence to Ana Christina Brasileiro-Vidal. Laboratório de Genética e Biotecnologia Vegetal, Departamento de Genética, Universidade Federal de Pernambuco, Av. Prof. Moraes Rego 1235, Cidade Universitária, 50670-901 Recife, PE, Brazil. E-mail: brasileirovidal.ac@gmail.com. used in natura or in compresses, and are considered to have anti-malarian (Jansen et al., 2010), insecticidal (Valencia et al., 2006), anti-inflammatory (Oliveira et al., 2010) and antimicrobial (Dhale and Birari, 2010; Gaikwad et al., 2012 ) properties. The root and stem have cytotoxic (Nazeema and Girija, 2013), anti-malarian, leishmanicidal, antimicrobial, insecticidal, molluscicidal (reviewed by Sabandar et al., 2013) and anti-inflammatory (Bhagat et al., 2013) properties. The seeds and fruits are used against influenza, and also as laxative (Sabandar et al., 2013), sedative, analgesic or anti-diarrheal agents (Apu et al., 2013). The latex, in turn, is bactericidal (Gaikwad et al., 2012) and molluscicidal (Matos, 2004). In Brazil, the topical application of latex in natura is employed against wounds and bites of venomous animals (Stasi and Hiruma-Lima, 2002), and its ingestion in diluted form is used for treatment of diarrhea by indigenous peoples (Curto, 1993). In India, the solution of latex with mustard oil (Brassica campestris) and clove oil (Syzygium aromaticum) is applied onto painful gum or teeth (Punjaji, 2012), whereas in the south of Ni- 
geria it is used to reduce nosebleed and wounded skin (Oduola et al., 2007).

Despite its medicinal properties, the latex of $J$. gossypiifolia in natura, in direct contact with the skin, may produce caustic and irritating effects (Parente and Rosa, 2001). Moreover, the aqueous extract of latex was shown to be toxic for fish as well as upon intraperitoneal administration to house mice, presenting significant reduction of acetylcholinesterase (AChE) inhibition in the first (Singh and Singh, 2012; Pratap and Singh, 2013) and seizures in the latter (Singh and Singh, 2012). The inhibition of AChE prevents the degradation of choline neurotransmitters, such as acetylcholine, and prolongs the signal transmission through synapses. Consequently, it may lead to lethal paralysis by hyperstimulation of the nervous system (Stansley, 1993). The toxic effect may be mainly associated to cyclic peptides of the latex (Horsten et al., 1996; Auvin-Guette et al., 1997; Pratap and Singh, 2013), which show cytotoxic activity, as related for other Jatropha species (reviewed by Sabandar et al., 2013). Therefore, complementary studies are still necessary for the latex of $J$. gossypiifolia to be safely employed for medicinal purposes, starting with the evaluation of its toxic potential.

Whereas the toxicity tests in animals lead to their death, alternative analysis should be considered. In this sense, genotoxicity tests using the Allium cepa test system showed a good correlation with the test system of mammals (Rank and Nielsen, 1994), indicating its use as an alternative for monitoring the genotoxic potential of chemical compounds (Fachinetto et al., 2007). Additionally, A. cepa stands out among other plants due to presenting large chromosomes and in few number $(2 n=16)$ in its cells (Fiskesjo, 1985). Moreover, the A. cepa test system has high sensitivity in detecting chemical and environmental agents (Leme and Marin-Morales, 2009). This system is easy to use and presents itself as a suitable bioindicator for the first screening of genotoxicity, thanks to its low cost, reliability and concordance with other genotoxicity tests. This way it contributes in the preliminary genotoxicity assessment of compounds for medicinal purposes (Bagatini et al., 2007). Thus, the present work aimed at analyzing the toxic, cytotoxic and genotoxic effects of the latex from $J$. gossypiifolia by means of the $A$. cepa test system.

\section{Material and Methods}

\section{Biological material}

Latex of $J$. gossypiifolia was collected from an adult plant in Teresina (PI, Brazil) in January 2013. Herbarium specimens containing leaves, flowers and fruits were stored in the Afrânio Fernandes at the State University of Piauí Herbarium (UESPI - Teresina, Brazil); voucher specimen number: HAF 03111. The seeds of $A$. cepa (cv. Vale Ouro IPA - 11) used in the bioassays were kindly provided by the Agronomic Institute of Pernambuco (IPA, Recife, Brazil).
The latex of $J$. gossypiifolia was extracted following removal of the leaf petioles using pruning shears, at 8 to $9 \mathrm{am}$. The latex was immediately stored in Falcon tubes wrapped in aluminum foil in order to reduce the oxidation process. The latex was then transported, in cooling box containing ice, to the Laboratory of Plant Genetics and Biotechnology (Genetics Department, UFPE) where it was diluted in distilled water to yield five different latex concentrations $(1.25 ; 2.5 ; 5 ; 10$ and $20 \mathrm{~mL} / \mathrm{L})$ to be used at $A$. cepa assay.

\section{Allium cepa assay}

One hundred seeds of A. cepa (cv. Vale Ouro IPA 11) were germinated in Petri dishes containing filter paper moistened with distilled water, at room temperature. When the rootlets reached about $1 \mathrm{~cm}$ in length, they were transferred to the five cited latex concentrations (one dish for each concentration) for $24 \mathrm{~h}$. Distilled water was used as negative control (NC); MMS (methyl methanesulfonate $4 \mathrm{x}$ $10^{-4} \mathrm{M}$ ), a drug with clastogenic activity, and the herbicide Trifluralin ( $0.84 \mathrm{ppm}$ of the active agent), a substance with aneugenic activity (Fernandes et al., 2007), were used as positive controls. When rootlets reached about $1.5 \mathrm{~cm}$ length, the material was fixed in Carnoy (ethanol:acetic acid $3: 1, \mathrm{v} / \mathrm{v}$ ) for $6-8 \mathrm{~h}$, at room temperature, and stored at $-20{ }^{\circ} \mathrm{C}$ until slide preparation.

For slide preparation, the root tips were washed three times in distilled water, for 5 min each time, and hydrolyzed at $60^{\circ} \mathrm{C}$ for $10 \mathrm{~min}$ in $\mathrm{HCl} 1 \mathrm{~N}$. After hydrolysis, the root tips were again washed in distilled water and transferred to amber glass bottles containing Schiffs reagent, in which they remained for $2 \mathrm{~h}$ in the dark. After this time, the root tips were washed until complete removal of the reagent, transferred onto slides, squashed with one drop of $2 \%$ acetic carmine, and mounted with Entellan ${ }^{\circledR}$.

Latex toxicity was evaluated according to the mean root length variation (in centimeters) of 30 roots per treatment. The experimental unit consisted of one individual root (one root per specimen). Cytotoxicity and genotoxicity were evaluated by scoring 5,000 meristematic cells (experimental unit: slide with 500 cells, with a total of 10 analyzed slides per treatment) under light microscope $(400 \mathrm{x})$. The assessed aspects were: (1) mitotic index (cytotoxicity) and (2) chromosome alteration index (genotoxicity). The last one includes alterations resulting from aneugenic effects (e.g. C-metaphases, metaphase with chromosome adherences, loss chromosomes, multipolar anaphases, binucleate cells, polyploid metaphases, and other alterations) or clastogenic effects (e.g. chromosome fragments in metaphase or anaphase, chromosome bridges and other alterations). Micronuclei can be result from either aneugenic or clastogenic effects.

Photographs of the best cells were taken in a Leica conventional microscope (DM 500) (1000 x), using a digital camera (Nikon 14.0 Megapixels). Images were adjusted 
for brightness and contrast, in gray tones using Adobe Photoshop CS6.

\section{Statistical Analysis}

The toxicity values were expressed as averages, whereas the values of cytotoxicity and genotoxicity were expressed as frequencies. Statistical analysis to evaluate data distribution with regard to normality was carried out by Lilliefors test (D) in the program Assistat 7.7 (Silva and Azevedo, 2002), while homogeneity of variance was evaluated by the Cochran test in the program BioEstat 5.3 (Ayres et al., 2007). Data which did neither present normal distribution nor homogeneity were analyzed by the nonparametric test of Kruskal-Wallis, followed by the a posteriori Student-Newman-Keuls test $(\mathrm{p}<0.05)$ in the program BioEstat 5.3 (Ayres et al., 2007). The data on cytotoxicity were the only presenting normal distribution and homogeneity of variance, and were analyzed by the parametric test of Scott-Knott $(\mathrm{p}<0.05)$ in the program Assistat 7.7 (Silva and Azevedo, 2002).

\section{Results}

The tests of toxicity and cytotoxicity carried out with seeds of $A$. cepa exposed to the different concentrations of latex from J. gossypiifolia showed a significant reduction in root mean growth and in mitotic index (MI) values of all tested latex concentrations, when compared to $\mathrm{NC}$, except for $1.25 \mathrm{~mL} / \mathrm{L}$. In these analyses, the reduction was partially or entirely dose-dependent for root mean growth and in mitotic index, respectively (Table 1).

With regards to chromosome alterations (CA), the increase in the total indexes (Table 2; Figure 1) was highly significant when compared with NC results, except for the 10 and $20 \mathrm{~mL} / \mathrm{L}$ concentrations. From these results, we may infer that $J$. gossypiifolia latex has a genotoxic action. On the other hand, the nemployed empirically in the popular medicine of maon-significant $\mathrm{CA}$ frequencies found for the higher latex concentrations (10 and $20 \mathrm{~mL} / \mathrm{L}$ ) may result from MI reduction with these treatments.

When the chromosome alterations were analyzed separately, metaphases with chromosome adherences (Figure 1A) have been found in all the treatments carried out with the latex; nevertheless significant $\mathrm{NC}$ related results were only recorded for the three lower concentrations $(1.25 ; 2.5$ and $5 \mathrm{~mL} / \mathrm{L})$. The presence of C-metaphases (Figure 1B) was significant only for 2.5 and $5 \mathrm{~mL} / \mathrm{L}$ concentrations (Table 2). Both chromosome adherences and $\mathrm{C}$-metaphases are result from aneugenic mechanisms.

Other non-significant alterations in chromosome segregation during anaphase and telophase were registered, such as chromosome losses (Figure 1C) and multipolarities (Figure 1D-E; Table 2). Additionally, polyploid (Figure 1F) and binucleated cells (Figure 1G), nuclear buds (Figure 1H) and lobulated nuclei (Figure 1I) have been found in all analyzed treatments, although no significant al- terations have been observed for any concentration (Table 2).

Chromosome fragments (Figure 1J) and chromosome bridges (Figure 1K; Table 2), arising from clastogenic effects, were also registered, but only the presence of chromosome bridges was significant for concentrations $1.25,5$ and $10 \mathrm{~mL} / \mathrm{L}$. Non-significant micronucleus (Figure $1 \mathrm{~L}$ ) frequencies were also observed.

\section{Discussion}

The latex of $J$. gossypiifolia is broadly used in popular medicine in many countries. However, this plant has phytochemicals in its composition such as alkaloids and cyclic peptides, which may be toxic to users (Singh and Singh, 2012; Pratap and Singh, 2013). In the present study, the test system $A$. серa was used to evaluate the toxic, cytotoxic and genotoxic effects of different concentrations $(1.25 ; 2.5$; $5 ; 10$ and $20 \mathrm{~mL} / \mathrm{L}$ ) of latex from J. gossypiifolia. The concentrations tested were selected based on a usage concentration recommended in popular medicine (approximately $10 \mathrm{~mL} / \mathrm{L}$, corresponding to one tablespoon in one liter of water). Apart from the recommended concentration, others were also tested based on results of latex toxicity in fish, which varied from 10 to $21.5 \mathrm{~mL} / \mathrm{L}$ (Singh and Singh, 2012; Pratap and Singh, 2013), but mainly on antimicrobial activity data, which varied from 1.9 to $4.4 \mathrm{~mL} / \mathrm{L}$ (Patil et al., 2012) for the latex of J. gossypiifolia and from 0.5 to 10 $\mathrm{mL} / \mathrm{L}$ for the latex of J. curcas (Arekemase et al., 2011).

The bioassays carried out here revealed dose-dependent toxicity (mean root growth) and cytotoxicity (mitotic index) for all analyzed treatments except for the lowest concentration $(1.25 \mathrm{~mL} / \mathrm{L})$. These effects may be attributed to various chemical substances present in the latex of $J$. gossypiifolia, mainly cyclic peptides ( $\mathrm{CPi}$ ), such as cyclogossines A (Horsten et al., 1996) and B (Auvin-Guette et al., 1997), terpenes (Patil et al., 2012) and alkaloids that have cytotoxic activity (Sabandar et al., 2013). Peptides present in other species of the genus Jatropha have also been reported as cytotoxic, such as integerrimides A and B of J. integerrima (Mongkolvisut et al., 2006) and the curcacyclins A and B of J. curcas (Insanu et al., 2012).

Cyclic peptides have a cyclical conformation (Sakai et al., 1996), which facilitates their passing through cell membranes, as well as absent exposure of the C- and $\mathrm{N}$-terminal groups to exopeptidases (Wu et al., 2007). These characteristics may be related to the ease with which these peptides enter and remain inside cells of $A$. серa, causing toxic effects, as observed here and in previous studies with latex of $J$. curcas in Artemia salina as well as in cell culture of human ovarian cancer (Insanu et al., 2012). On the other hand, terpenes, such as diterpenes, are some of the most toxic compounds in Jatropha (Devappa et al., 2011), whereas lipophilic nature (Wink, 2012) facilitates their entry and remaining inside cells of $A$. cepa, causing toxic effects. Additionally, terpenes in latex may be associated 
with a reduction in calcium concentration, thus inhibiting protein kinase $\mathrm{C}(\mathrm{PKC})$, as observed in leaf ethanol extract of J. gossypiifolia (Silva et al., 1995; Paes et al., 2012), decreasing cell proliferation (Alberts et al., 2010). Similar results were observed with inhibitors of PKC in A. cepa (Blume et al., 2008), Arabidopsis thaliana (Sheremet et al., 2010) and Nicotiana tabacum (Sheremet et al., 2012).

In the current study, most chromosome alterations (CA), such as chromosome adherences and C-metaphases, were considered a result of genotoxic effects, since they represent damage to the genetic material which is not necessarily fixed in the organism (Leme and Marin-Morales, 2009; Mazzeo et al., 2011). When these alterations can be repaired, they are not transmitted to descendant cells (Ventura-Camargo et al., 2011). The presence of chromosome adherences and C-metaphases confirms the interference of phytochemicals of $J$. gossypiifolia latex in the assembly, stabilization and/or inactivation of spindle fibers, characterizing an aneugenic activity of the latex.

Aneugenic activities in metaphase may generate other types of cell abnormalities such as multipolar anaphases, nuclear buds, lobulated nuclei, and polyploid cells (Fernandes et al., 2009). However, these alterations were not significant in the present study, what indicates that chromosome adherences and C-metaphases did not contribute to further alterations, and suggests a reversible mechanism for them (Odeigah et al., 1997).

Chromosome bridges, chromosome fragments and part of micronucleus formation are related to clastogenic activity (Fenech et al., 2011). Chromosome bridges and fragments, for instance, could be the result of chromosome breakage-fusion-bridge cycles, elucidated for the first time by Barbara McClintock in the 1930s in maize chromosomes (reviewed by Jones, 2005). However, chromosome

Table 1 - Values of mean length for the root tips of Allium cepa and mitotic indexes in meristematic cells, observed $24 \mathrm{~h}$ after Jatropha gossypiifolia latex treatment at different concentrations.

\begin{tabular}{lcc}
\hline Latex treatment $(\mathrm{mL} / \mathrm{L})$ & Mean root length $(\mathrm{cm})$ & Mitotic index $(\%)$ \\
\hline Distilled water $(\mathrm{NC})^{1}$ & $3.32 \pm 0.90$ & $51.57 \pm 2.69 \mathrm{a}^{5}$ \\
1.25 & $3.21 \pm 0.89$ & $51.77 \pm 6.63 \mathrm{a}$ \\
2.5 & $2.43 \pm 0.64^{* * 4}$ & $44.33 \pm 5.53 \mathrm{~b}$ \\
5 & $2.11 \pm 0.64^{* *}$ & $36.70 \pm 5.27 \mathrm{c}$ \\
10 & $2.28 \pm 0.85^{* *}$ & $36.32 \pm 5.43 \mathrm{c}$ \\
20 & $1.87 \pm 0.62^{* *}$ & $22.02 \pm 8.00 \mathrm{~d}$ \\
MMS $\left(4 \times 10^{-4} \mathrm{M}\right)^{2}$ & $2.78 \pm 0.63$ & $36.67 \pm 7.11 \mathrm{c}$ \\
Trifluralin $(0.84 \mathrm{ppm})^{3}$ & $2.38 \pm 0.69^{* *}$ & $23.00 \pm 2.76 \mathrm{~d}$ \\
\hline
\end{tabular}

${ }^{1} \mathrm{NC}$ : negative control. ${ }^{2} \mathrm{MMS}$ (Methyl methanesulfonate): positive control. ${ }^{3}$ Trifluralin: positive control. ${ }^{4}$ Significant in the Kruskal-Wallis test with a posteriori Student-Newman-Keuls test $\left({ }^{*} \mathrm{p}<0.05\right.$; $\left.{ }^{* *} \mathrm{p}<0.01\right)$. ${ }^{5}$ Scott-Knott test $(p<0.05$; averages followed by the same lowercase letter are not significantly different). The results refer to analysis of 5,000 cells per treatment.

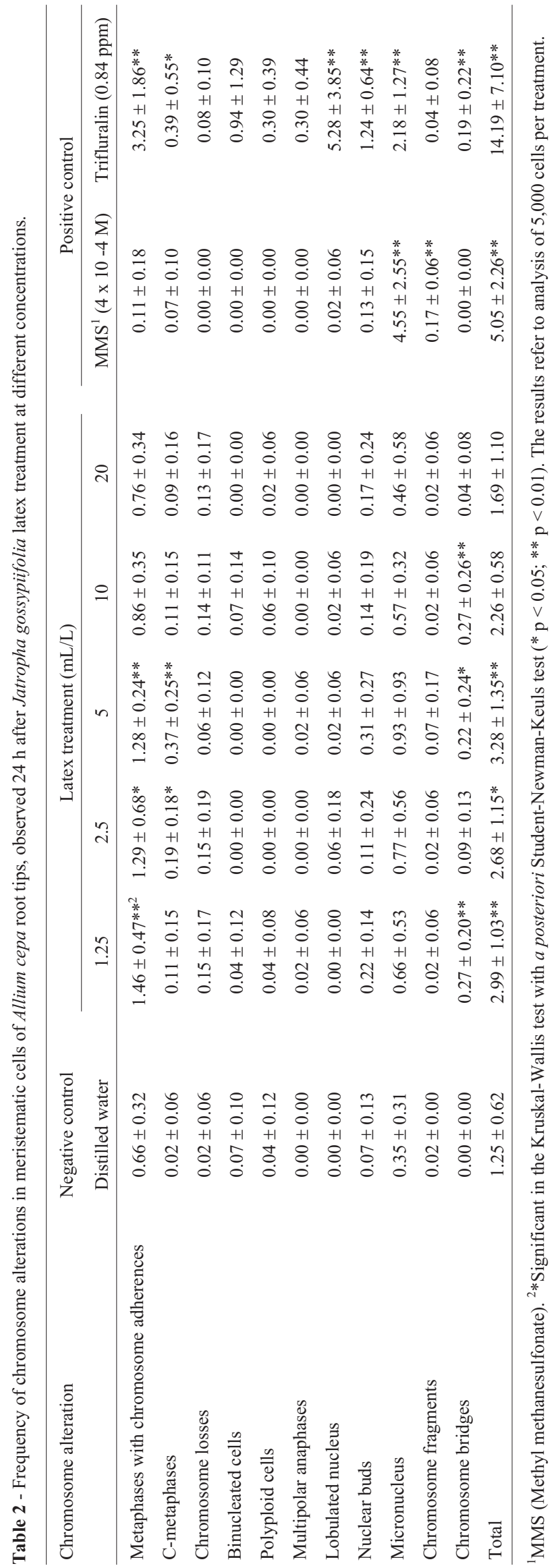



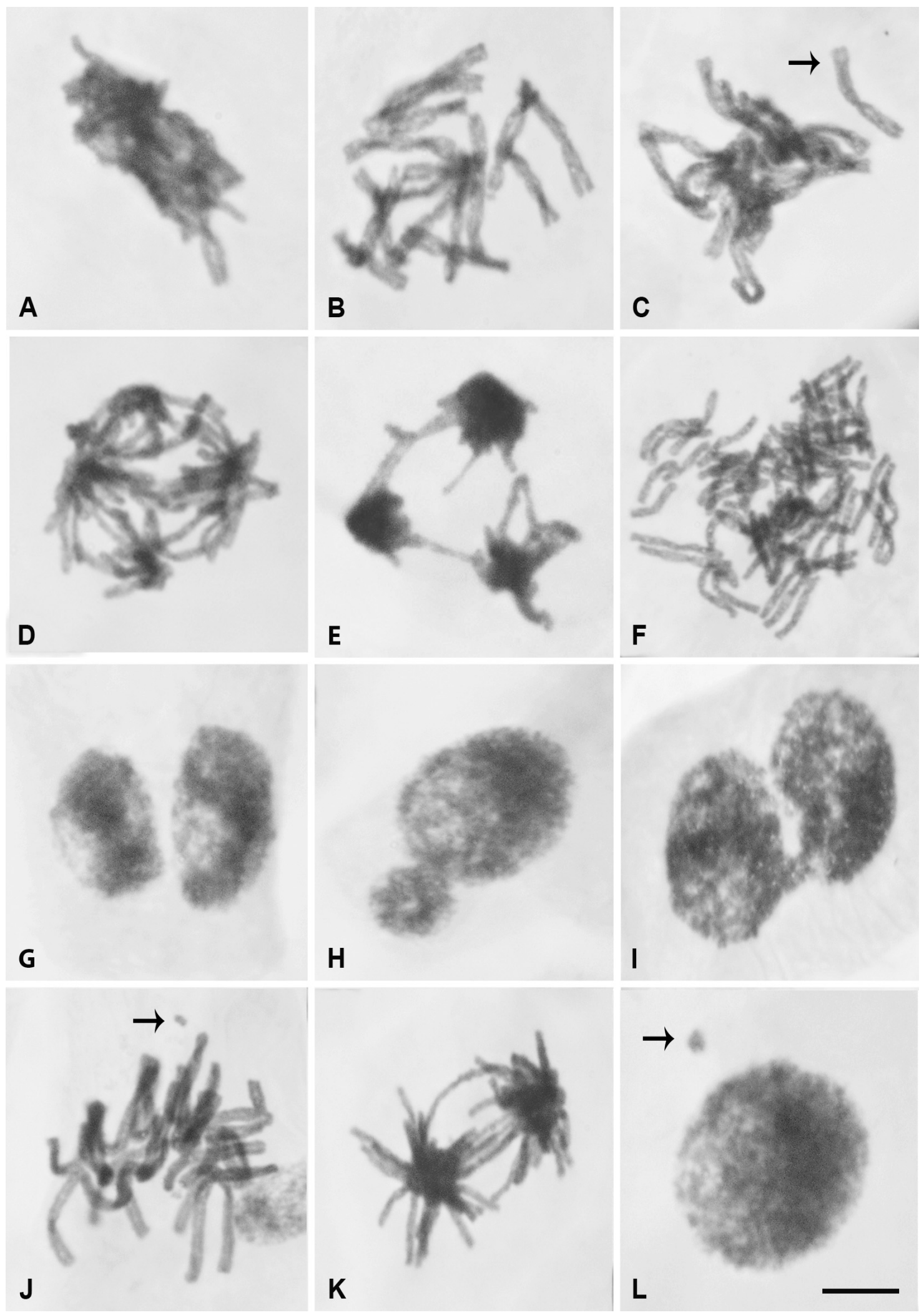

Figure 1 - Chromosome alterations after Jatropha gossypiifolia latex treatment of Allium cepa meristematic cells. (A) Chromosomal adherence (1.25 $\mathrm{mL} / \mathrm{L}$ ). (B) C-metaphase $(5 \mathrm{~mL} / \mathrm{L})$. (C) Metaphase with chromosome loss $(2.5 \mathrm{~mL} / \mathrm{L})$. (D) Multipolar anaphase with chromosome bridges (5 mL/L). (E) Multipolar telophase with chromosome bridges $(5 \mathrm{~mL} / \mathrm{L})$. (F) Polyploid metaphase $(10 \mathrm{~mL} / \mathrm{L})$. (G) Binucleated cell $(10 \mathrm{~mL} / \mathrm{L})$. (H) Nucleus with nuclear bud $(5 \mathrm{~mL} / \mathrm{L})$. (I) Lobulated nucleus $(2.5 \mathrm{~mL} / \mathrm{L})$. (J) Metaphase with chromosome fragment $(5 \mathrm{~mL} / \mathrm{L})$. (K) Anaphase with chromosome bridge $(10 \mathrm{~mL} / \mathrm{L})$. (L) Micronucleated cell $(1.25 \mathrm{~mL} / \mathrm{L})$. Arrows in $(\mathrm{C}),(\mathrm{J})$ and $(\mathrm{L})$ indicate chromosome loss, chromosome fragment and micronucleus, respectively. Bar: $10 \mu \mathrm{m}$ (for all pictures). 
fragments could also be induced by several factors involved in DNA breaks (Fenech, 2000). On the other hand, micronuclei formation could be induced by both aneugenic and clastogenic activities, related to entire chromosomes or chromosome fragments (respectively) not incorporated into the main nucleus during the cell cycle (Fenech et al., 2011). In the present results, from these three clastogenic alterations, only chromosome bridges had a significant increase.

The clastogenic alterations triggered by the latex indicate a chromosome mutagenic potential. This type of alteration represents damage to the genetic material at chromosome level that could not be repaired by the cell, being possibly transmitted to descendant cells (Grant, 1978). Furthermore, J. gossypiifolia latex caused toxicity and cytotoxicity at the tested concentrations, except for $1.25 \mathrm{~mL} / \mathrm{L}$. It also generated significant alterations in the assembly and stabilization of the mitotic spindle fibers, resulting in disturbance of the cell cycle and chromosome alterations for all concentrations. Based on these last results, it can be inferred that the mechanism of action of the latex also has aneugenic nature.

Although $J$. gossypiifolia is considered an important potential plant for the generation of pharmacological and/or biotechnological products (Félix-Silva et al., 2014), overall, the tests performed indicated toxicity, cytotoxicity and genotoxicity of $J$. gossypiifolia latex, including the concentrations acknowledged as antimicrobial (1.9 and 4.4 $\mathrm{mL} / \mathrm{L}$ ) (Patil et al., 2012). Considering that the latex of $J$. gossypiifolia is employed empirically in the popular medicine of many countries, and that the A. cepa test system presents good correlation with the tests carried out in mammals (Rank and Nielsen, 1994), it should be pointed out that it may potentially harm the human health especially if ingested. In addition, other studies with this plant material are necessary in order to elucidate the mechanisms of action of its bioactive compounds, and to reduce its toxicity while keeping its therapeutic action, for further use of isolated latex compounds in the pharmaceutical industry.

\section{Acknowledgments}

We are grateful to the Federal University of Pernambuco (UFPE) and the State University of Piauí (UESPI) for providing the installations and infrastructure for realization of the present study; to Dr. Francisco Soares Filho, for taxonomic identification of the botanic material $(J$. gossypiifolia); and to Dr. Fátima de Oliveira Pires for technical help with microscopy. This work was supported by fellowship within the Post-Graduation Promotion Program (PROF) from the Coordenação de Aperfeiçoamento de Pessoal de Nível Superior (CAPES/Brazil), and research grants from the Conselho Nacional de Desenvolvimento Científico e Tecnológico (CNPq) and FACEPE (Fundação de Amparo à Ciência e Tecnologia do Estado de Pernambuco).

\section{References}

Alberts B, Bray D, Lewis J, Raff M, Roberts K and Watson JD (2010) Biologia Molecular da Célula. $5^{\text {a }}$ edition. Artes Médicas Sul LTDA, São Paulo, 1396 pp.

Apu AS, Hossain F, Rizwan F, Bhuyan SH, Matin M and Jamaluddin ATM (2013) Study of pharmacological activities of metanol extract of Jatropha gossypifolia fruits. J Basic Clin Pharm 4:20-24.

Arekemase MO, Kayode RMO and Ajiboye AE (2011) Antimicrobial activity and phytochemical analysis of Jatropha Curcas plant against some selected microorganisms. Int $\mathrm{J}$ Biol 3:52-59.

Auvin-Guette C, Baraguey C, Blond A, Pousset JL and Bodo B (1997) Cyclogossine B, a cyclic octapeptide from Jatropha gossypifolia. J Nat Prod 60:1155-1157.

Ayres M, Ayres JRM, Ayres DL and Santos AS (2007) BioEstat 5.3 - Aplicações Estatísticas nas Áreas das Ciências Biomédicas. Sociedade Civil Mamirauá, Belém, 364 pp.

Bagatini DM, Silva ACF and Tedesco SB (2007) Uso do sistema teste de Allium cepa como bioindicador de genotoxicidade de infusões de plantas medicinais. Rev Bras Farmacogn 17:444-447.

Bhagat R, Misar AV, Ambavade SD and Kulkarni DK (2013) HPTLC analysis and anti-inflammatory activity of Jatropha gossypifolia L. root in mice and wistar rats. IJPR 3:13-17.

Blume Y, Yemets A, Sulimenko V, Sulimenko T, Chan J, Lloyd C and Draber P (2008) Evidence of tyrosine phosphorylation of plant tubulin. Planta 229:143-150.

Çelik TA and Aslantürk OS (2010) Evaluation of cytotoxicity and genotoxicity of Inula viscosa leaf extracts with Allium test. J Biomed Biotechnol 2010:1-8.

Curto LA (1993) Índio: Manual de Saúde. Aldo Lo Curto, Canzo, 208 pp.

Devappa RK, Makkar HPS and Becker K (2011) Jatropha diterpenes: A review. J Am Oil Chem Soc 88:301-322.

Dhale DA and Birari R (2010) Preliminary screening of antimicrobial and phytochemical studies of Jatropha gossypifolia L. Rec Res Sci Tech 2:24-28.

Fachinetto JM, Bagatini MD, Durigon J, Silva ACF and Tedesco SB (2007) Efeito anti-proliferativo das infusões de Achyrocline satureioides DC (Asteraceae) sobre o ciclo celular de Allium cepa. Rev Bras Farmacogn 17:49-54.

Félix-Silva J, Giordani RB, Silva-Jr AA, Zucolotto SM and Pedrosa MFF (2014) Jatropha gossypiifolia L. (Euphorbiaceae): A review of traditional uses, phytochemistry, pharmacology, and toxicology of this medicinal plant. Evid Based Complement Alternat Med 2014:1-32.

Fenech M (2000) The in vitro micronucleus technique. Mutat Res 455:81-95.

Fenech M, Kirsch-Volders M, Natarajan AT, Surralles J, Crott JW, Parry J, Norppa YH, Eastmond DA, Tucker JD and Thomas P (2011) Molecular mechanisms of micronucleus, nucleoplasmic bridge and nuclear bud formation in mammalian and human cells. Mutagenesis 26:125-132.

Fernandes TCC, Mazzeo DEC and Marin-Morales MA (2007) Mechanism of micronuclei formation in polyploidizated cells of Allium cepa exposed to trifluralin herbicide. Pestic Biochem Physiol 88:252-259.

Fernandes TCC, Mazzeo DEC and Marin-Morales MA (2009) Origin of nuclear and chromosomal alterations derived from 
the action of an aneugenic agent Trifluralin herbicide. Ecotox Environ Safe 72:1680-1686.

Fiskesjo G (1985) The Allium test as a standard in environmental monitoring. Hereditas 102:99-112.

Gaikwad RS, Kakde RB, Kulkarni AU, Gaikwad DR and Panchal VH (2012) In vitro antimicrobial activity of crude extracts of Jatropha species. Curr Bot 3:09-15.

Grant WF (1978) Chromosome aberrations in plants as a monitoring system. Environ Health Persp 27:37-43.

Horsten SF, Berg AJVD, Bosch JJKVD, Leeflang BR and Labadie RP (1996) Cyclogossine A: A novel cyclic heptapeptide isolated from the latex of Jatropha gossypifolia. Planta Med 62:46-50.

Insanu M, Anggadiredja J and Kayser O (2012) Curcacycline A and B - New pharmacological insights to an old drug. IJARNP 5:26-34.

Jansen O, Angenot L, Tits M, Nicolas JP, Mol DP, Nikiema JB and Frederich M (2010) Evaluation of 13 selected medicinal plants from Burkina Faso for their antiplasmodial properties. J Ethnopharmacol 130:143-150.

Jones RN (2005) McClintock's controlling elements: The full story. Cytogenet Genome Res 109:90-103.

Leme DM and Marin-Morales MA (2008) Chromosome aberration and micronucleus frequencies in Allium cepa cells exposed to petroleum polluted water - A case study. Mutat Res 650:80-86.

Leme DM and Marin-Morales MA (2009) Allium cepa test in environmental monitoring: A review on its application. Mutat Res 7934:1-11.

Matos FJA (2004) Constituintes químicos ativos e propriedades biológicas de plantas medicinais brasileiras. Editora UFC, Fortaleza, 448 pp.

Mazzeo DEC, Fernandes TCC and Marin-Morales MA (2011) Cellular damages in the Allium cepa test system, caused by BTEX mixture prior and after biodegradation process. Chemosphere 85:13-18.

Mongkolvisut W, Sutthivaiyakit S, Leutbecher H, Mika S, Klaiber I, Moller W, Rosner H, Beifuss U and Conrad J (2006) Integerrimides A and B, cyclic heptapeptides from the latex of Jatropha integerrima. J Nat Prod 69:1435-1441.

Nazeema TH and Girija S (2013) Characterisation of the active antiproliferative principles of Jatropha curcus and Jatropha gossippifolia on Hela cell lines. Int J Pharm Pharm Sci 5:346-355.

Nunes LG, Gontijo DC, Souza CJA, Fietto LG, Carvalho AF and Leite JPV (2012) The mutagenic, DNA-damaging and antioxidative properties of bark and leaf extracts from Coutarea hexandra (Jacq.) K. Schum. Environ Toxicol Pharmacol 3:297-303.

Odeigah PGC, Nurudeen O and Amund OO (1997) Genotoxicity of oil field wastewater in Nigeria. Hereditas 126:161-167.

Oduola T, Popoola GB, Avwioro OG, Oduola TA, Ademosun AA and Lawal MO (2007) Use of Jatropha gossypifolia latex as a haemostatic agent: How safe is it? J Med Plants Res 1:14-17.

Oliveira FCS, Barros RFM and Neto MJM (2010) Plantas medicinais utilizadas em comunidades rurais de Oeiras, semiárido piauiense. Ver Bras P1 Med 12:282-301.

Paes AMA, Camara AL, Freire SMF and Borges MOR (2012) Relaxant effect of Jatropha gossypiifolia L. on uterine smooth muscle. International Journal of phytomedicine 4:310-313.
Parente CET and Rosa MMT (2001) Plantas comercializadas como medicinais no Município de Barra do Piraí, RJ. Rodriguésia 52:47-59.

Patil SV, Borase HP, Patil CD and Salunke BK (2012) Biosynthesis of silver nanoparticles using latex from few Euphorbian plants and their antimicrobial potential. Appl Biochem Biotechnol 167:776-790.

Pawlowski Â, Kaltchuk-Santos E, Zini CA, Caramão EB, Sudhakar GLGS, Gowda R and Venu NG (2012) Essential oils of Schinus terebinthifolius and S. molle (Anacardiaceae): Mitodepressive and aneugenic inducers in onion and lettuce root meristems. S Afr J Bot 80:96-103.

Ping KY, Darah I, Yusuf UK, Yeng C and Sasidharan S (2012) Genotoxicity of Euphorbia hirta: An Allium cepa Assay. Molecules 17:7782-7791.

Pratap B and Singh A (2013) Piscicidal and anti AChE activity of medicinal plant Jatropha gossypifolia (FamilyEuphorbiaceae). World J Fish and Marine Sci 5:367-372.

Punjaji SA (2012) Traditional oral healthcare practices in pathardi areas of Ahmednagar district, Maharashtra, India. Environ Pharmacol Life Sci 1:84-88.

Rank J and Nielsen MH (1994) Evaluation of the Allium anaphase-telophase test in relation to genotoxicity screening of industrial wastewater. Mutat Res 312:17-24.

Ray S, Kundu LM, Goswami S, Roy GC, Chatterjee S, Dutta S, Chaudhuri A and Chakrabarti CS (2013) Metaphase arrest and delay in cell cycle kinetics of root apical meristems and mouse bone marrow cells treated with leaf aqueous extract of Clerodendrum viscosum Vent. Cell Prolif 46:109-117.

Sabandar CW, Ahmat N, Jaafar FM and Sahidin I (2013) Medicinal property, phytochemistry and pharmacology of several Jatropha species (Euphorbiaceae): A review. Phytochemistry 85:7-29.

Sakai R, Rinehart KL, Kishore V, Kundu B, Faircloth G, Gloer JB, Carney JR, Namikoshi M, Sun F, Hughes RG, et al. (1996) Structure and activity relationships of the didemnins1,2. J Med Chem 39:2819-2834.

Sheremet YA, Emets AI, Azmib A, Vissenberg K, Verbelen JP and Blume YB (2012) Effect of serine/threonine protein kinases and protein phosphatases inhibitors on mitosis progression in a synchronized tobacco BY-2 culture. Cytol Genet 46:89-95.

Sheremet YA, Yemets AI, Vissenberg K, Verbelen JP and Blume YB (2010) Effects of inhibitors of serine/threonine protein kinases on Arabidopsis thaliana root morphology and microtubule organization in its cells. Cell Tissue Biol 4:399-409.

Silva AM, Brum RL and Calixto JB (1995) The relaxant action of jatrophone in rat portal vein. A comparison with protein kinase C inhibitors. Life Sci 57:863-871.

Silva FAS and Azevedo CAV (2002) Versão do programa computacional Assistat para o sistema operacional Windows. Revista Brasileira de Produtos Agroindustriais 4:71-78.

Singh P and Singh A (2012) Acute toxic effects of medicinal plant Jatropha gossypifolia on non- target fish and mice. Wudpecker J Agric Res 1:433-438.

Stansley W (1993) Field results using cholinesterase reactivation techniques to diagnose acute anticholinesterase poisoning in birds and fish. Arch Environ Com Tox 25:315-321. 
Stasi DLC and Hiruma-Lima CA (2002) Plantas Medicinais na Amazônia e na Mata Atlântica. 2 edition. Editora da UNESP, São Paulo, 604 pp.

Valencia A, Frérot B, Guénego H, Múnera DF, Sá MFGD and Calatayud PA (2006) Effect of Jatropha gossypiifolia leaf extracts on three lepidoptera species. Rev Colomb Entomol 32:45-48.

Ventura-Camargo BC, Maltempi PPP and Marin-Morales MA (2011) The use of the cytogenetic to identify mechanisms of action of an azo dye in Allium Cepa meristematic cells. J Environment Analytic Toxicol 1:1-12.

Wink M (2012) Medicinal plants: A source of anti-parasitic secondary metabolites. Molecules 17:12771-12791.

Wu L, Lu Y, Zheng QT, Tan NH, Li CM and Zhou J (2007) Study on the spatial structure of annomuricatin A, a cyclohexa- peptide from the seeds of Annona muricata. J Mol Struct $827: 145-148$

\section{Internet Resources}

Cordeiro I and Secco R (2014) Jatropha in Lista de Espécies da Flora do Brasil. Jardim Botânico do Rio de Janeiro. http://floradobrasil.jbrj.gov.br/jabot/floradobrasil/FB17581 (Accessed on March 20, 2014).

Associate Editor: Carlos F.M. Menck

License information: This is an open-access article distributed under the terms of the Creative Commons Attribution License, which permits unrestricted use, distribution, and reproduction in any medium, provided the original work is properly cited. 